\title{
EDITORIAL: CON UNA CARTA EN LA MANGA
}

\section{EDITORIAL: WITH A LETTER UP YOUR SLEEVE}

\author{
Víctor Amar \\ Director de Hachetetepé. Revista científica de educación y comunicación \\ Universidad de Cádiz, España \\ https://orcid.org/0000-0001-9036-2651 \\ victor.amar@uca.es
}

Cómo citar este artículo: Amar, V. (2020). Editorial: Con una carta en la manga. Hachetetepé. Revista cientifica en Educación y Comunicación, (20),1-2,doi: http://doi.org/10.25267/Hachetetepe.2020.i20.1

En Cádiz a 28 de febrero de 2020, día de Andalucía

Leer cartas te lleva a conocer el parecer, creencia o sensibilidad de otra persona e, incluso, te ayuda a atisbar su estado anímico o emocional, deseo o frustración. Y escribirlas contribuye a crecer, igualmente, como persona.

Un egodocumento que, infelizmente, ha caído en el olvido e, igualmente, en la desconsideración. Tal vez, esté pasado de moda o se le ha permitido que el modelo tradicional de escritura a puño y letra quedase sustituido por la inmediatez de la virtualidad; que es el modo actual de perpetuar a las cartas. Pero en el fondo siguen siendo cartas escritas o dictadas donde nos quitamos el disfraz, en alusión a los tiempos de carnaval que la coordinadora del número de la revista hace alusión, o nos podemos una máscara para persuadir. Sea lo que fuera, escribimos; continuamos escribiendo cartas. Ahora bien, de un tiempo hacia acá, hemos diversificado la escritura. Ya no son simples palabras impresas sobre un papel, el cual personalizábamos con nuestra manera singular de trazar las letras, o bien con dibujos que evidenciaban la intención de nuestro escrito o de grecas que bordeaban el papel delimitando la mirada del lector. Ahora, también, se audiodescriben o se tornan textos audiovisuales o multimediáticos. La presencia del hipermedia, que todo lo invade, asimismo, está presente en las cartas que circulan a velocidad vertiginosa por los senderos del siglo XXI.

El caminho único de la carta se ha roto. Ya no va del escriba al receptor. La hipersimplificación ha hecho que con un simple clic la carta llegue a un sinnúmero de narratarios. Y aquí entra en acción la red de receptores. Lo que antes tenía su concreción para quien la recibiera; ahora se torna una acción múltiple, para muchos y muchas; en diferentes partes del mundo y accesible en cualquier momento... Y luego la carta se puede hacer extensa pues, en ocasiones, la hacemos viral. Pero lo importante no es solo la cantidad sino la calidad de las mismas. Y, por ello, hacemos una reflexión, es más hacemos hincapié en este idea de que lo importante es lo qué narramos. Es decir, lo que aflora de nuestra intención de compartir. Es como deseáramos desprendernos de nuestra fantasía carnavalesca y mostrarnos tal como somos. Pero sabemos que eso es imposible pues en la vida como en el carnaval, o bien como en las cartas, hace falta un poco de fabulación, tal como cuenta la profesora Ercília en su símil con la cigarra y la hormiga.

Creemos que en esto de las cartas existen dos grandes bloques que desfilan entre las calles llenas de confetis y algarabía carnavalesca. Los cartafílicos y los cartafóbicos. Pero han emergido fruto de la contemporaneidad los conocidos como los "tecnocárticos"; 
o sea, entusiastas de las tecnologías y los textos en forma de misivas. En pleno siglo XXI la diversidad también ha llegado a las cartas. Pero, no vale con este pretexto. Hace falta tener y saber contar algo a los demás. Pensemos un poco en este principio que, quizás, nos haga cambiar y comprender la militancia de estas personas (autoras y autores de los diferentes artículos) que gentilmente, como un gesto de generosidad, comparten con nosotras y nosotros sus pareceres, experiencias y necesidades expresivas sobre las cartas. $\mathrm{Y}$ todos las aportaciones possen un sesgo educativo o profesional, sociológico o de compromisso con el valor de las cartas. Comparten sus escritos con los demás. Y comparten en la doble acepción que ofrece la Real Academia de la Lengua Española (RAE): a) la de repartir y b) en la que hacemos más hincapié, pues se centra en la necesidad de hacer partícipe a los demás.

Lean con atención este conjunto de "cartas" (muchas de ellas vinculadas a la educación social). Y, ojalá, este número, que ya es el XX de la revista http, le haga hacerte autor de cartas. Y contribuya a considerarlas como un ejercicio recreativo y de honestidad, de apertura y sinceridad con uno mismo y con o hacia los demás.

Vivan las cartas.

Son algo más que un simple papel escrito (o en la pantalla). Éstas se tornan en un ejercicio pro comunicativo y pro comunitario... Donde la reciprocidad entra en acción y hacen que los atabaques, los pandeiros o las marchiñas de carnaval estén y suenen en todos los lugares (parafraseando a la compañera coordenadora del presente número de la revista).

Y siempre permanecerá en el membrete de la carta el agradecimiento a la profesora y doctora, Ercilia Maria Angeli Teixeira de Paula, de la Universidad Estadual de Maringá -UEM- Paraná, Brasil; y a todas las personas que han hecho posible este compendio de cartas a ambos lados del estrecho Atlántico (Brasil, Argentina, Uruguay, Colombia o Portugal) ... Y, por último, acabarías el escrito com un gracias al valor de las cartas...

Bueno, antes de acabar, no estaría de más hacer alusión a la nueva etapa que comenzamos. Conformamos parte del elenco de revistas científicas de la Universidad de Cádiz. Una nueva etapa, una nueva ilusión con nuevos desafíos. Son veinte número, diez años y muchos deseos que hacer realidad... 